\title{
Prevention of hypothermia in newborn submitted to surgical procedures: an integrative review
}

\author{
Prevenção da hipotermia em recém-nascido submetido a procedimentos cirúrgicos: revisão integrativa \\ Prevención de la hipotermia en recién nacido procedimientos quirúrgicos: revisión integrativa
}

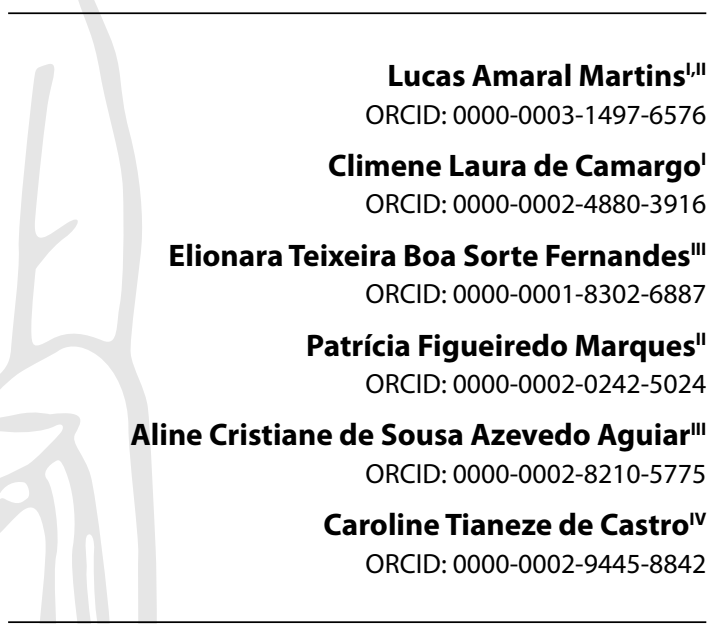

'Universidade Federal da Bahia. Salvador, Bahia, Brazil. "Universidade Federal do Recôncavo da Bahia. Santo Antônio de Jesus, Bahia, Brazil.

"'Universidade do Estado da Bahia. Guanambi, Bahia, Brazil. " Universidade Federal da Bahia. Vitória da Conquista, Bahia, Brazil.

How to cite this article: Martins LA, Camargo CL, Fernandes ETBS, Marques PF, Aguiar ACSA, Castro CT. Prevention of hypothermia in newborn submitted to surgical procedures: an integrative review. Rev Bras Enferm. 2022;75(1):e20200940. https://doi.org/10.1590/0034-7167-2020-0940

Corresponding author:

Lucas Amaral Martins

E-mail: lucas.martins@ufrb.edu.br

EDITOR IN CHIEF: Dulce Barbosa ASSOCIATE EDITOR: Priscilla Broca

Submission: 09-14-2020

Approval: 04-27-2021

\section{ABSTRACT}

Objective: to discuss in the scientific literature the strategies used to prevent hypothermia in newborns undergoing surgical procedures. Methods: this is an integrative literature review, with structured search in April and May 2020 in 08 databases, using the descriptors: Hypothermia; Surgical Procedures, Operative; Infant, Newborn; Protocols. Four primary studies were selected and analyzed using three instruments to assess the methodological quality of the Joanna Briggs Institute and content analysis. Results: Among the strategies used, the following stand out: room temperature control; establishment of humidification and quality of air conditioning cleanliness; use of a heated incubator or cradle; use of thermal mattress; use of caps and blanket; heated fluids; temperature monitoring and abdominal organ coverage. Conclusion: good hypothermia prevention strategies were identified, despite the small number of publications on this topic; thus, it points out the need for research with strong evidence.

Descriptors: Infant, Newborn; Hypothermia; Surgical Procedures, Operative; Disease Prevention; Neonatal Nursing.

\section{RESUMO}

Objetivo: discutir, na literatura científica, as estratégias utilizadas para prevenção de hipotermia em recém-nascido submetido a procedimentos cirúrgicos. Métodos: revisão integrativa de literatura, com busca estruturada em abril e maio de $2020 \mathrm{em} 08$ bases de dados, utilizando os descritores: Hypothermia; Surgical Procedures, Operative; Infant, Newborn; Protocols. Foram selecionados e analisados 04 estudos primários por meio de três instrumentos para avaliação da qualidade metodológica da Joanna Briggs Institute e da análise de conteúdo. Resultados: dentre as estratégias utilizadas destaca-se: controle da temperatura ambiente; estabelecimento de umidificação e qualidade de limpeza do ar condicionado; utilização de incubadora ou berço aquecido; uso de colchão térmico; uso de toucas e cobertor; fluidos aquecidos; monitoramento da temperatura; cobertura de órgãos abdominais. Conclusão: identificaram-se boas estratégias de prevenção de hipotermia, apesar de haver um número reduzido de publicações nesta temática; dessa forma, aponta-se a necessidade de pesquisas com evidências fortes.

Descritores: Recém-Nascido; Hipotermia; Procedimento Cirúrgico; Prevenção; Enfermagem Neonatal.

\section{RESUMEN}

Objetivo: discutir, en la literatura científica, las estrategias utilizadas para prevenir la hipotermia en recién nacidos sometidos a procedimientos quirúrgicos. Métodos: revisión integrativa de la literatura, con búsqueda estructurada en abril y mayo de 2020 en 08 bases de datos, utilizando los descriptores: Hypothermia; Surgical Procedures, Operative; Infant, Newborn; Protocols. Se seleccionaron y analizaron cuatro estudios primarios utilizando tres instrumentos para evaluar la calidad metodológica del Instituto Joanna Briggs y el análisis de contenido. Resultados: entre las estrategias empleadas destacan: control de la temperatura ambiente; establecimiento de humidificación y calidad de aire acondicionado limpio; uso de una incubadora o cuna con calefacción; uso de colchón térmico; uso de gorros y mantas; fluidos calentados; monitoreo de temperatura; cobertura de órganos abdominales. Conclusión: se identificaron buenas estrategias de prevención de la hipotermia, a pesar del escaso número de publicaciones sobre este tema; por lo tanto, señala la necesidad de realizar investigaciones con evidencia sólida. Descriptores: Recién Nacido; Hipotermia; Procedimientos Quirúrgicos Operativos; Prevención de Enfermedades; Enfermería Neonatal. 


\section{INTRODUCTION}

Inadvertent hypothermia in a surgical procedure is a problem for patients worldwide and is associated with harmful side effects ${ }^{(1)}$. In newborns (NBs), hypothermia is characterized by a reduction in body temperature reaching values below $36.5^{\circ} \mathrm{C}^{(2)}$. This is the result of an internal redistribution of body heat from the nucleus to the periphery, followed by heat loss greater than metabolic production ${ }^{(3)}$.

In NBs, thermal control is in the maturation and adaptation phase, therefore, to maintain normothermia it is necessary to have a balance between the production and the elimination of heat ${ }^{(4)}$. Ineffective thermoregulation is one of the main complications that affect NB, since hypothermia predisposes to metabolic disorders, respiratory distress, enterocolithenecrotizing and intracranial hemorrhage $\mathrm{e}^{(5-6)}$. The thermoregulatory mechanism is, therefore, considered a critical function for the survival of $\mathrm{NBs}^{(5-6)}$.

Providing an environment that favors NB normothermia is a strong predictor of reduced morbidity and mortality at all gestational ages, being considered an indicator of quality of $\operatorname{care}^{(7)}$, meeting the principles that guide patient safety strategies, which are defined as the absence of avoidable damage and the reduction of unnecessary risks associated with health care to an acceptable minimum, in order to reduce the occurrence of adverse events (AEs). AEs are characterized by incidents that result in unintentional damage to patient ${ }^{(8-9)}$, thus hypothermia in surgical NB is considered as an AE.

Accidental hypothermia is a frequent occurrence during neonatal surgery, which indicates the importance of developing evidence-based warming strategies for prevention ${ }^{(10)}$. NBs that present hypothermia in the intra and/or postoperative period will have a greater number of AEs when compared to normothermic ones ${ }^{(11)}$. In Canadian hospitals, it was found that there is a greater proportion of $A E$ in surgical NBs when compared to clinical $\mathrm{NBs}^{(12)}$.

A study reveals that $A E s$ in relation to hypothermia in surgical patients constitutes a health problem and its incidence varies between $26 \%$ and $90 \%$, with half of these events being preventable ${ }^{(13)}$. Even though surgical treatment aims to save lives, security breaches and uncontrolled risks during surgical care can cause irreparable damage to patients ${ }^{(14)}$. Thus, it is necessary to have an accurate view of health professionals and, in particular, the nursing team, for prevention of hypothermia in surgical $\mathrm{NBs}^{(15)}$.

In this sense, the need for studies that aim to: identify the procedures that predispose to perioperative hypothermia is highlighted; determine the relative value of quality improvement interventions; characterize the morbidity and mortality associated with perioperative hypothermia in neonatal patients ${ }^{(16)}$; seek new methods and care strategies for surgical NB, ensuring quality care, safe and free from risks and damage ${ }^{(15)}$. There is still a high incidence of inadvertent hypothermia in the perioperative period ${ }^{(1)}$.

Given the above, the need for an integrative literature review emerged as a way to synthesize the national and international scientific evidence in this context of care for surgical NBs.

\section{OBJECTIVE}

To discuss in the scientific literature the strategies used to prevent hypothermia in newborns undergoing surgical procedures.

\section{METHOD}

\section{Ethical aspects}

The study respected national and international ethical principles, maintaining the ideas of the authors of the publications used in the development of this study.

\section{Research design}

This is an integrative literature review, a method that allows the broad analysis of a given subject, with deep knowledge about the proposed theme, allowing discussions about methods, results and conclusions from selected studies as well as reflections on conducting future studies ${ }^{(17)}$.

The construction of this research was structured in five stages, according to the proposal of Whittemore and Knafl(18): elaboration of the research question and/or identification of objectives; literature search; data evaluation; analysis of studies; presentation of the integrative review results.

The Cumulative Index to Nursing \& Allied Health Literature (CINAHL) and the National Library of Medicine (PubMed) databases were consulted. No systematic bibliographic research on the prevention of hypothermia in NBs submitted to surgical procedures was found, coupled with the absence of protocols and systematic review reports registered in the Joanna Briggs Institute (JBI) collections in the Prospective Register of Systematic Review (PROSPERO) and Cochrane Library.

\section{Research question development}

The question that guided the research was: what are the strategies used to prevent hypothermia in NBs submitted to surgical procedures? Its elaboration was based on the PICO strategy (Population; Intervention; Comparison; Outcomes) ${ }^{(19)}$, being P- NB, submitted to surgical procedures, I - strategies used to prevent hypothermia, $\mathrm{C}$ - not applicable and $\mathrm{O}$ - prevention of hypothermia.

\section{Literature search}

Search for primary studies was carried out in April and May 2020 in the Scientific Electronic library online (SCIELO), Latin American and Caribbean Literature in Health Sciences (LILACS), Medical Literature Analysis and Retrieval System Online (MEDLINE), National Library of Medicine (PubMed), Cumulative Index to Nursing and Allied Health Literature (CINAHL), Excerpta Medica Database (Embase) and Web of Science databases. Google Scholar was also used, using the advanced search method. The descriptors were delimited according to the Medical Subject Headings (MeSH) and Health Sciences Descriptors (DeCS), being used: Hypothermia; Surgical Procedures, Operative; Infant, Newborn; Protocols. In the search strategy implemented for the crossing, the Boolean operator "AND" was used to associate the descriptors, as shown in Table 1.

Original articles published in full and addressing the topics on strategies for prevention of hypothermia in surgical NB, methods of thermal control in surgical procedure, thermal control of the surgical environment for NB, technologies used in the prevention of hypothermia in surgical NB were included. There was no 
language restriction and initial investigation time limiting the final time to 2020, since there were no changes in the basic principles of thermal control over the years; however, new technological resources were added in order to qualify the care, thus enabling a breadth in the investigative process.
The articles' level of evidence was assessed according to the classification model proposed by $\mathrm{JBI}^{(21)}$. Considering that both cohort studies, as well as the case-control study have high methodological quality and low risk of bias, the evidence found is level III according to the JBI classification, being included in this review.
Table 1 - References found at the respective crossings ( $n=201$ ), 2021

\begin{tabular}{llc}
\hline DATABASE & SEARCH STRATEGY & $\begin{array}{c}\text { Number of } \\
\text { articles }\end{array}$ \\
\hline CINAHL & "Hypothermia" and "Surgical Procedures, Operative" and "Infant, Newborn" & 5 \\
MEDLINE & "Hypothermia" and "Surgical Procedures, Operative" and "Infant, Newborn" & 18 \\
SciELO & "Hypothermia" and "Surgical Procedures, Operative" & 8 \\
& "Hypothermia" and "Infant, Newborn" & 17 \\
"Hypothermia" and "Infant, Newborn" and "protocols" & 15 \\
PubMed & "Hypothermia" and "Surgical Procedures, Operative" and "Infant, Newborn" & 1 \\
Web Of Science & "Hypothermia" and "Surgical Procedures, Operative" and "Infant, Newborn" & 7 \\
& "Hypothermia" and "Surgical Procedures, Operative" and "Infant, Newborn" & 1 \\
& "Hypothermia" and "Infant, Newborn" & 6 \\
"Hypothermia" and "Infant, Newborn" and "protocols" & 30 \\
Gmbase & "Hypothermia" and "Surgical Procedures, Operative" and "Infant, Newborn" & 10 \\
\hline
\end{tabular}

\section{Data analysis}

Critical analysis of the studies was based on content analysis(22), in order to present the scientific evidence about the best practices used for prevention of hypothermia in NBs submitted to surgical procedures. The articles were read in a dynamic and cyclical back and forth process that allowed for data reduction, data presentation and verification of conclusions, thus enabling the visualization of four categories of analysis for the presentation of results ${ }^{(22)}$.

To present the studies included in the integrative review, the flowchart

Gray literature (thesis, dissertation, monographs, books, protocols, manuals, among other non-indexed documents) and documents that did not answer the research question were excluded. After selecting the articles, they were submitted to the Mendeley bibliographic management tool, in order to exclude duplicate articles $(n=14)$.

\section{Data assessment}

The investigation and selection of articles was carried out by 02 independent researchers, with the sequence of use of descriptors and crosses in each database being standardized. Then, results obtained and consensus among researchers were compared, so that each article was examined by title, abstract and full text, according to the inclusion and exclusion criteria established.

After selecting the articles, the researchers performed a critical assessment of methodological quality using three JBI instruments: JBI Critical Appraisal Checklist for Cohort Studies, JBI Critical Appraisal Checklist for Case Control Studies and JBI Critical Appraisal Checklist for Case Series ${ }^{(20)}$. The first assesses the methodological quality of cohort studies, the second, casecontrol, and the third, case series.

In these instruments, each question must be answered through four options: yes $(\mathrm{Y})$, no (N), unclear (U) and not applicable (NA). The calculation of percentage of risk of bias and methodological quality is performed by the amount of "Y" selected in the checklist. Questions where the answers are "NA" are not included in the final calculation. The answers " $\mathrm{N}$ " and " $\mathrm{U}$ " do not score in the calculation. Studies with scores of up to $49 \%$ are considered to be at high risk of bias and low methodological quality; between $50 \%$ and $70 \%$, the risk and methodological quality are moderate; above $70 \%$, the risk of bias is low and the methodological quality is high. proposed by PRISMA (Preferred Reporting Items for Systematic Reviews and Meta-Analyzes) ${ }^{(23)}$ was used, as shown in Figure 1, as well as charts containing information on study characteristics, strategies, outcomes and recommendations.

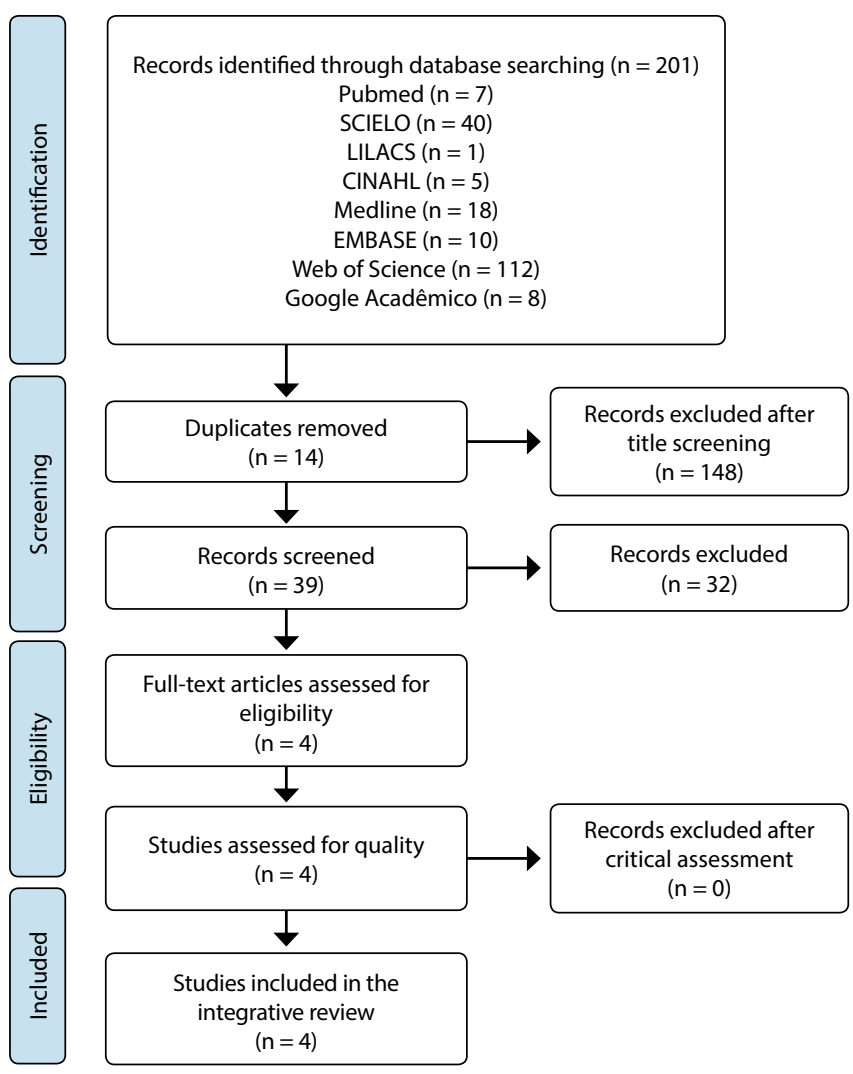

Figure 1 - Informative flowchart of integrative review phases anchored in PRISMA, 2021 


\section{RESULTS}

After searching in database and according to established selection criteria, this integrative review included four articles ${ }^{(11,24-26)}$, which are presented in Chart 1. These were distributed in PubMed ( $2 ; 50 \%)$, followed by Embase $(1 ; 25 \%)$ and MEDLINE $(1 ; 25 \%)$ databases, published in the last 50 years, totaling as a sample $268 \mathrm{NBs}$ submitted to surgical procedures.

The studies used methodologies with quantitative approaches, and the language of all articles was English, and the publications in medicine ${ }^{(24-26)}$ and nursing ${ }^{(11)}$.

In assessing the articles'methodological quality, the scores ranged from $50 \%$ to $100 \%$ and all had the same level of evidence according to JBI.

The strategies, outcome and recommendations for hypothermia reduction presented in the selected articles are described in Chart 3. The main strategy in the prevention of hypothermia in surgical NB presented in the studies was thermal environment control in which surgery is performed ${ }^{(11,24-26)}$.

Other strategies for prevention of hypothermia in surgical procedures are also identified, namely: use of thermal mattress, chemical or heated blankets ${ }^{(11,24-25)}$; caps, overalls, and blankets ${ }^{(11,24-25)}$; use of a previously heated incubator or heated cradle ${ }^{(11,24-26)}$; infusion of heated fluids ${ }^{(11,24-26)}$; monitoring of body temperature in the axillary, nasopharyngeal, esophageal or rectal regions ${ }^{(11,24)}$; perioperative temperature measurement routines ${ }^{(11,24)}$; coverage of abdominal organs with wet and heated surgical compresses ${ }^{(25)}$; establishment of relative air humidification ${ }^{(24,26)}$; air conditioning cleaning quality ${ }^{(26)}$ and heat lamps ${ }^{(11)}$.

The strategies used to prevent hypothermia in surgical NB are varied and can be categorized into: environment care ${ }^{(11,24-26)}$; NB care related to temperature monitoring and the use of technological equipment ${ }^{(11,24-26)}$; NB care related to preparing for surgery ${ }^{(11,24,26)}$; care related to the use of solutions, liquids, fluids and blood products $^{(11,24-25)}$. It appears that hypothermia is a real and unresolved $A E$ in the studies ${ }^{(11,24-26)}$ analyzed. Thus, it points to the need for professionals involved in the care of surgical NB to rethink their practices and develop effective care protocols that stratify these data and develop actions that meet the clinical, environmental, structural and care demands in the prevention of hypothermia in surgical NB.

Chart 1 - Characteristics of articles, 2021

\begin{tabular}{|c|c|c|c|c|}
\hline Reference & $\begin{array}{l}\text { Year/ } \\
\text { Country }\end{array}$ & Objective & $\begin{array}{l}\text { Design/number } \\
\text { of patients }\end{array}$ & Journal \\
\hline $\begin{array}{l}\text { Tsingoglo and } \\
\text { Wilkinson }{ }^{(24)}\end{array}$ & $\begin{array}{l}1971 \\
\text { England }\end{array}$ & Describe the causes of heat loss in NBs undergoing surgery. & $\begin{array}{l}\text { Case series } \\
\quad \mathrm{n}=37\end{array}$ & $\begin{array}{l}\text { Archives of } \\
\text { Disease in } \\
\text { Childhood }\end{array}$ \\
\hline Tander et al $\mathrm{l}^{(25)}$ & $\begin{array}{l}2005 \\
\text { Turkey }\end{array}$ & $\begin{array}{l}\text { Assess the factors that led to intraoperative hypothermia in } 60 \text { ( } 31 \\
\text { neonates and } 29 \text { infants). }\end{array}$ & $\begin{array}{c}\text { Cohort } \\
\mathrm{n}=60\end{array}$ & $\begin{array}{l}\text { Pediatric } \\
\text { Anesthesia }\end{array}$ \\
\hline Morehouse et al $\left.\right|^{(11)}$ & $\begin{array}{l}2014 \\
\text { England }\end{array}$ & $\begin{array}{l}\text { Describe the perioperative thermal instability of NBs and identify } \\
\text { where (surgical center and Neonatal Intensive Care Unit) and } \\
\text { when (pre, intra and/or postoperative) occurs; describe adverse } \\
\text { cardiovascular, respiratory and metabolic outcomes associated with } \\
\text { hypothermia; describe supportive interventions and diagnostic } \\
\text { tests associated with hypothermia. }\end{array}$ & $\begin{array}{l}\text { Case-control study } \\
\qquad \mathrm{n}=108\end{array}$ & $\begin{array}{l}\text { Advances in } \\
\text { Neonatal Care }\end{array}$ \\
\hline He et $\mathrm{al}^{(26)}$ & $\begin{array}{l}2018 \\
\text { China }\end{array}$ & $\begin{array}{l}\text { Report experience in performing surgical procedures in a Neonatal } \\
\text { Intensive Care Unit, including air cleaning. }\end{array}$ & $\begin{array}{c}\text { Cohort } \\
\mathrm{n}=92\end{array}$ & $\begin{array}{l}\text { Medicine } \\
\text { (Baltimor) }\end{array}$ \\
\hline
\end{tabular}

Chart 2 - Assessment of methodological quality of articles through three Joanna Briggs Institute (JBI) instruments, 2021

\begin{tabular}{|c|c|c|c|c|c|c|c|c|c|c|c|c|c|}
\hline \multicolumn{13}{|c|}{ JBI Critical Appraisal Checklist for cohort studies } & JBI \\
\hline STUDY & Q1 & Q2 & Q3 & Q4 & Q5 & Q6 & Q7 & Q8 & Q9 & Q10 & Q11 & SCORE & $\begin{array}{l}\text { Level of } \\
\text { evidence }\end{array}$ \\
\hline Tander et al. ${ }^{(25)}$ & Y & Y & $\mathrm{Y}$ & Y & Y & Y & Y & Y & Y & NA & Y & $100.0 \%$ & 3 \\
\hline He et al. ${ }^{(26)}$ & Y & Y & $\mathrm{Y}$ & $\mathrm{N}$ & $\mathrm{N}$ & $\mathrm{Y}$ & Y & Y & Y & NA & Y & $80.0 \%$ & 3 \\
\hline \multicolumn{13}{|c|}{ JBI Critical Appraisal Checklist for case-control studies } & JBI \\
\hline STUDY & Q1 & Q2 & Q3 & Q4 & Q5 & Q6 & \multicolumn{2}{|c|}{ Q7 } & Q8 & Q9 & Q10 & SCORE & $\begin{array}{l}\text { Level of } \\
\text { evidence }\end{array}$ \\
\hline $\begin{array}{l}\text { Morehouse } \\
\text { et al. } .^{(11)}\end{array}$ & $\mathrm{N}$ & Y & Y & Y & $\mathrm{Y}$ & Y & \multicolumn{2}{|c|}{ Y } & Y & Y & Y & $90.0 \%$ & 3 \\
\hline \multicolumn{13}{|c|}{ JBI Critical Appraisal Checklist for case series studies } & JBI \\
\hline STUDY & Q1 & Q2 & Q3 & Q4 & Q5 & Q6 & & & Q8 & Q9 & Q10 & SCORE & $\begin{array}{l}\text { Level of } \\
\text { evidence }\end{array}$ \\
\hline $\begin{array}{l}\text { Tsingoglou e } \\
\text { Wilkinson }^{(24)}\end{array}$ & Y & Y & U & U & U & $N$ & & & Y & $N$ & Y & $50.0 \%$ & 3 \\
\hline
\end{tabular}

JBI - Joanna Briggs Institute. 
Chart 3 - Strategies, outcome and recommendations of articles for reducing hypothermia, 2021

\begin{tabular}{|c|c|c|c|}
\hline Reference & $\begin{array}{l}\text { Strategies used to prevent hypothermia } \\
\text { in surgical newborn }\end{array}$ & Outcome & Recommendations \\
\hline $\begin{array}{l}\text { Tsingoglou and } \\
\text { Wilkinson }^{(24)}\end{array}$ & $\begin{array}{l}\text { - Transport incubator temperature of } 32^{\circ} \mathrm{C}(29.2 \text { to } \\
35.6^{\circ} \mathrm{C} \text { average); } \\
\text { - NB covered to the shoulders with sweater; } \\
\text { - Room temperature of the operating room }(22.7 \text { to } \\
\left.28^{\circ} \mathrm{C} \text {, with average of } 25.7^{\circ} \mathrm{C}\right) ; \\
- \text { Temperature of the microclimate }\left(27.2 \text { to } 38.5^{\circ} \mathrm{C} \text {, with }\right. \\
\left.\text { average of } 32.4^{\circ} \mathrm{C}\right) ; \\
\text { - Relative air humidity during surgery ranged from } 32 \% \\
\text { to } 62 \% \text {, with an average of } 43 \% \text {; } \\
\text { - Fixation of thermometer in the axillary, abdominal and } \\
\text { close to the rectum region; } \\
\text { - NB temperature check at } 15-\text { minute intervals. } \\
\text { - Electric heated mattress }\left(37 \text { to } 42^{\circ} \mathrm{C}\right) ; \\
\text { - All cleaning solutions and intravenous fluids except } \\
\text { blood were kept in a cabinet at a temperature between } \\
40 \text { and } 43^{\circ} \mathrm{C} ; \\
\text { - Heated blood products. }\end{array}$ & $\begin{array}{l}\text { - } 17 \mathrm{NB} \text { evolved with an average } \\
\text { normothermia of } 36.9^{\circ} \mathrm{C} \text {; } \\
-7 \mathrm{NB} \text { evolved with an average } \\
\text { hyperthermia of } 38.3^{\circ} \mathrm{C} \text {; } \\
-13 \mathrm{evolved} \text { with an average hypothermia } \\
\text { of } 35.9^{\circ} \mathrm{C} \text {; } \\
\text { - There were small temperature changes } \\
\text { in the surgery, but some patients went } \\
\text { to the operating room with subnormal } \\
\text { temperatures; } \\
\text { - The postoperative period was quiet, except } \\
\text { in a NB with septicemia (temperature } \\
\text { of } 39.5^{\circ} \mathrm{C} \text { ) having to be cooled after the } \\
\text { operation; } \\
\text { - The microclimate temperature varied } \\
\text { between } 32.8 \text { and } 42^{\circ} \mathrm{C} \text {. } \\
\text { - In the rapid infusion of } 10 \text { ml of cold blood } \\
\text { a drop of } 0.1^{\circ} \mathrm{C} \text { in the rectal temperature } \\
\text { occurred in } 7 \text { patients, but this did not occur } \\
\text { when the blood in the syringe was heated } \\
\text { for the first time in the electric blanket. }\end{array}$ & $\begin{array}{l}\text { - Establish the temperature } \\
\text { of } 37 \text { to } 42^{\circ} \mathrm{C} \text { for the electric } \\
\text { mattress; } \\
\text { - Before the surgery, NBs } \\
\text { must be protected with } \\
\text { some type of tissue, such } \\
\text { as a blanket/blanket, since } \\
\text { there is repeated opening of } \\
\text { the incubator doors for NB } \\
\text { examinations; } \\
\text { - When it is necessary to } \\
\text { transfuse large volumes of } \\
\text { blood, the microclimate } \\
\text { may have to be kept at a } \\
\text { higher temperature to avoid } \\
\text { cooling NBs. }\end{array}$ \\
\hline Tander et $\mathrm{al}^{(25)}$ & $\begin{array}{l}\text { - Two temperature parameters were established for } \\
\text { surgery on NBs: low }\left(20.5 \text { to } 23^{\circ} \mathrm{C}\right) \text { and high }(23.5 \\
\left.\text { to } 27^{\circ} \mathrm{C}\right) \text {. } \\
\text { Perioperative interventions: } \\
\text { - Hot gel mattresses/compresses, with a } \\
\text { temperature of } 39^{\circ} \mathrm{C} ; \\
\text { - Liquids and fluids heated to } 37^{\circ} \mathrm{C} ; \\
\text { - Blood products heated to } 37^{\circ} \mathrm{C} ; \\
\text { - The abdominal organs were covered with moist } \\
\text { and warm compresses at } 37^{\circ} \mathrm{C} ; \\
\text { - Head, legs and arms covered with warm cotton pads; } \\
\text { - NB covered with heated surgical wrap. }\end{array}$ & $\begin{array}{l}\text { - The type of surgery and the operating } \\
\text { room temperature are factors that affect NBs' } \\
\text { temperature. } \\
\text { - Major surgeries were } 2.66 \text { times more likely } \\
\text { to decrease core temperature; } \\
\text { - Operating rooms with temperature }<23^{\circ} \mathrm{C} \\
\text { have } 1.96 \text { times more chance of lowering the } \\
\text { core temperature, compared to rooms with } \\
\text { temperatures }>23^{\circ} \mathrm{C} \text {. }\end{array}$ & $\begin{array}{l}\text { - In major surgeries it is } \\
\text { necessary to use thermal } \\
\text { resources to guarantee NB } \\
\text { normothermia; } \\
\text { - The operating room } \\
\text { temperature must be } \\
\text { adjusted according to the } \\
\text { type and size of surgery; } \\
\text { - The main factors that } \\
\text { predispose to hypothermia } \\
\text { are: type of surgery } \\
\text { and operating room } \\
\text { temperature. }\end{array}$ \\
\hline $\begin{array}{l}\text { Morehouse } \\
\text { et al }{ }^{(11)}\end{array}$ & $\begin{array}{l}\text { - Performing a surgical procedure in two different } \\
\text { environments, Neonatal Intensive Care Unit and } \\
\text { operating room; } \\
\text { Perioperative interventions: } \\
\text { - Heated incubators or cradles with radiant heat; } \\
\text { - Caps, extra blanket, heated blanket; } \\
\text { - Chemical mattress and thermal mattress; } \\
\text { - heated intravenous fluids; } \\
\text { - Monitoring of axillary, nasopharyngeal, esophageal or } \\
\text { rectal temperature. } \\
\text { Temperature record: } \\
\text { - Before transporting NB to the operating room; } \\
\text { - In the preoperative period, after delivery to the } \\
\text { operating room team or the arrival of the surgical team } \\
\text { at the Neonatal Intensive Care Unit; } \\
\text { - In the intraoperative period, continuous verification; } \\
\text { - In the postoperative period, check every } 15 \text { minutes, } \\
\text { in the } 1^{\text {st }} \text { hour; every } 30 \text { minutes, in the } 2^{\text {nd }} \text { hour; every } \\
\text { hour for } 4 \text { hours or until the temperature is stable. }\end{array}$ & $\begin{array}{l}\text { Hypothermia developed in } 40 \% \text { ( } n=43 \text { ) of } \\
\text { children during the perioperative period. } \\
\text { The operating room group had a higher } \\
\text { rate of perioperative hypothermia ( } 65.45 \% \text {, } \\
n=36 ; p<001 \text { ) and were } 7 \text { times more likely } \\
\text { to develop perioperative hypothermia } \\
\text { ( } p=008 \text { ) than the Neonatal Intensive Care } \\
\text { Unit group }(13.21 \%, n=7 \text { ). Likewise, NBs in the } \\
\text { operating room group were } 10 \text { times more } \\
\text { likely to develop hypothermia during intra } \\
\text { and postoperative periods than those in the } \\
\text { Neonatal Intensive Care Unit group. ( } p=001 \text { ). } \\
\text { The hypothermic group had significantly more } \\
\text { adverse respiratory events ( } p=025 \text { ), were } 6 \\
\text { times more likely to require thermoregulatory } \\
\text { interventions ( } p<001 \text { ). } \\
\text { Both groups experienced unacceptable rates } \\
\text { of clinical hypothermia. }\end{array}$ & $\begin{array}{l}\text { - Use of a cap before and } \\
\text { during surgery; } \\
\text { - Use preheated transport } \\
\text { incubator and heated } \\
\text { mattress when transferring } \\
\text { to the operating room; } \\
\text { - Use of a cap before and } \\
\text { during surgery; } \\
\text { - Use of a heated mattress } \\
\text { during surgical procedures; } \\
\text { - Intravenous fluids must be } \\
\text { preheated; } \\
\text { - In the postoperative } \\
\text { period, NBs must return to a } \\
\text { preheated bed; } \\
\text { - In family rooms of the } \\
\text { Neonatal Intensive Care Unit, } \\
\text { the room temperature must } \\
\text { be set at } 23.8^{\circ} \mathrm{C} \text {. }\end{array}$ \\
\hline He et $\mathrm{al}^{(26)}$ & $\begin{array}{l}\text { - Performing a surgical procedure in two environments; } \\
\text { - Neonatal Intensive Care Unit: Room temperature from } \\
23^{\circ} \text { to } 26^{\circ} \mathrm{C} \text {, air humidity ( } 50 \% \text { to } 60 \% \text { ), ISO } 14644-1 \text {, } \\
\text { evaluation of air conditioning cleanliness (Class 7); } \\
\text { - Operating room: room temperature at } 18^{\circ} \text { to } 22^{\circ} \mathrm{C} \text {, air } \\
\text { humidity ( } 55 \% \text { to } 75 \% \text { ), ISO } 14644-1 \text { evaluation of air } \\
\text { conditioning cleanliness (Class } 5 \text { and } 6 \text { ). } \\
\text { - Before surgery, NB were transferred to an incubator } \\
\text { and extra heaters for NB were added, according to } \\
\text { body temperature. }\end{array}$ & $\begin{array}{l}\text { Average postoperative body temperature was } \\
\text { significantly different between the } 2 \text { groups, } \\
\text { although it was similar before surgery }\left(36.4^{\circ} \mathrm{C}\right. \\
\text { in the Neonatal Intensive Care Unit group and } \\
\left.35.9^{\circ} \mathrm{C} \text { in the operating room group } \mathrm{p}=002\right) \text {. } \\
\text { The lowest body temperature during surgery } \\
\text { was } 35.2^{\circ} \mathrm{C} \text { in the operating room group, } \\
\text { which was significantly lower than in the } \\
\text { Neonatal Intensive Care Unit group }\left(36.1^{\circ} \mathrm{C},\right. \\
p<001) \text {. Four patients }(9.1 \%) \text { in the Neonatal } \\
\text { Intensive Care Unit group presented } \\
\text { hypothermia during surgery, compared with } \\
27 \text { patients }(56.3 \%) \text { in the operating room } \\
\text { group }(\mathrm{p}<001) \text {. }\end{array}$ & $\begin{array}{l}\text { - Suggests that performing } \\
\text { surgical procedures in a } \\
\text { Neonatal Intensive Care Unit } \\
\text { with air cleaning class } 7 \text { is as } \\
\text { safe as in an operating room. }\end{array}$ \\
\hline
\end{tabular}




\section{DISCUSSION}

There is a shortage of literature that evaluates neonatal thermal care strategies $^{(10)}$. This review also reveals that there is a reduced number of publications aimed at preventing hypothermia in NB undergoing a surgical procedure. The findings are concentrated in European and Asian countries and point to the need for research on this theme with strong evidence, outlined by methods of randomized clinical trials and cohort studies, since authors point out that the prevention of hypothermia is a critical determinant of neonatal morbidity and mortality ${ }^{(27)}$.

Implementing practices based on scientific evidence results in a significant reduction of hypothermia in neonates and become a standard of care ${ }^{(28)}$. This evidence is essential to support changes in care practices with NBs, allowing autonomy for multidisciplinary teams, supporting clinical practice, qualifying care safely and enabling innovation in the thermal control of $\mathrm{NBs}^{(29)}$.

Establishing a neutral thermal environment is essential for prevention of hypothermia in the NBs that will undergo surgery, since it provides a reduced metabolic expenditure of heat loss, a minimum consumption of calories and oxygen, thus allowing temperature stability with the loss of heat equal to production ${ }^{(30)}$.

Care with room temperature control was identified as the main concern in publications focused on the theme of neonatal thermal care ${ }^{(11,24-26)}$. Two articles ${ }^{(11,26)}$ compared the performance of a surgical procedure in different environments (Operating Room (OR) and Neonatal Intensive Care Unit (NICU)) and evaluated where there was a higher incidence of hypothermia in the NBs; another ${ }^{(25)}$ analyzes the OR temperature and correlates it with small and large surgeries and, finally, investigates ${ }^{(24)}$ the necessary strategies to provide the ideal surgical environment for maintaining normothermia in NBs. It is stipulated as thermal parameters of a neonatal operating room: room temperature with a variation of $22.7^{\circ} \mathrm{C}$ to $28^{\circ} \mathrm{C}^{(11,15,24-26,31-32)}$, air humidity control between $32 \%$ and $62 \%^{(24-26,32)}$ and quality of air cleaning, based on the International Standardization Organization (ISO) 14644-1 with numerical classes ${ }^{(26)}$.

Studies ${ }^{(11,26)}$ that compared surgical procedures in NICUs and OR identified that, in OR, the number of NBs that presented episodes of hypothermia was higher. The research ${ }^{(25)}$ that analyzes the temperature management of the OR in small and large sized procedures found that NBs that undergo major surgery cannot maintain thermal stability as well as NBs that undergo minor surgery size in very cold rooms. In view of this evidence, the researchers point out the need to use exogenous sources of heat as well as other actions to provide normothermia for surgical NB. Another $\operatorname{article}^{(24)}$ points out strategies and parameters for prevention of hypothermia in NB undergoing surgical procedures.

Scientific evidence also points to the use of equipment and accessories to provide an adequate environment and reduce NB heat losses, such as an incubator, heated cradle, thermal, chemical mattresses and heated blanket ${ }^{(11,15,24-26,31)}$.

NB care related to temperature monitoring and the use of technological equipment such as the cradle with radiant heat and the heated and humidified incubators provide a neutral thermal environment for NBs. Thus, this equipment monitors NBs' temperature via a skin sensor, which needs to be positioned in the axillary or abdominal region so that more accurate and safe monitoring occurs, since these equipment use feedback mechanisms to determine the production of heat and maintain normothermia ${ }^{(11,15,24,27)}$.

Thermal mattress is another resource that has been widely used in the prevention of NB hypothermia, with an adjustment temperature between $37^{\circ} \mathrm{C}$ and $42^{\circ} \mathrm{C}^{(11,15,24,27)}$. This has shown satisfactory results and should be used during all operative procedures, regardless of the duration of the procedure ${ }^{(11)}$. In the situation where the body temperature reaches a value above $37^{\circ} \mathrm{C}$, it is recommended that temperature is reduced or the blanket is turned off to neutralize the NB temperature ${ }^{(24)}$.

Thermal blanket is an effective method to correct hypothermia, since it allows the central temperature to rise by about $0.75^{\circ} \mathrm{C}$ in approximately one hour, being programmed with a temperature between $38^{\circ}$ and $40^{\circ} \mathrm{C}$; if used previously for 30 minutes to the procedure, this temperature recovery can drop to 30 minutes ${ }^{(33)}$.

In Chinese hospitals, other strategies have been shown to be effective, namely: heated and humidified $\mathrm{CO}_{2}$ insufflation $\left(35^{\circ} \mathrm{C}\right.$ temperature and $95 \%$ relative humidity) in laparoscopic surgeries ${ }^{(32)}$; rewarming of children with postoperative hypothermia with the combination of an electric blanket and a forced air heating system ${ }^{(34)}$. These resources were associated with positive postoperative results, including less tremors and hypothermia, faster recovery of bowel movements and shorter hospital stay ${ }^{(32)}$.

A Brazilian study ${ }^{(15)}$ points out actions used for thermal control similar to those identified in this review: i) keep NB involved in previously heated sweaters, when removing it from the incubator or heated cradle for transportation; ii) start the surgical procedure only when NBs present a normothermic state; iii) insert an esophageal thermometer before the surgical procedure for monitoring intraoperative temperature; iv) use a thermal blanket during major surgical procedures; v) monitor the temperature of NBs in the NICU after returning from the postoperative period, with a digital thermometer; vi) monitor the temperature of NBs at 15-minute intervals in situations that present a hyper or hypothermia chart; vii) administer solutions and blood products at an appropriate temperature. It should be noted that the fluids must be heated in thermoregulated greenhouses at an average temperature of $40^{\circ}$. Thus, when administered, infusions maintain a temperature between $37^{\circ} \mathrm{C}$ and $38^{\circ} \mathrm{C}(35)$.

Regarding NB care related to the preparation for surgery and fluids, European research ${ }^{(11)}$ recommends that, to prevent hypothermia in surgical NB, the orientation is: wearing a cap before and during surgery; transport must take place in a transport incubator preheated with the use of a chemical heating mattress; NICU heaters must be used intraoperatively within the OR parameters; intravenous fluids must be preheated; postoperatively, NBs must return to a preheated cradle or incubator ${ }^{(11)}$.

Another study ${ }^{(36)}$ confirms the importance of using the thermal blanket and transport incubator in the transfer of NB between UTN and OR, since the use of these resources reduces neonatal hypothermia in the intraoperative period and presents significant improvements in obtaining postoperative normothermia in seriously ill neonates.

Among the surgical stages, the immediate preoperative period presents the highest risk of hypothermia, as NBs undergo clinical 
procedures and interventions, such as anesthetic induction, orotracheal intubation, venous access and soundings, which are usually performed with the exposed neonate and without an additional heat source. These actions predispose to heat loss and to reach the stabilization of body temperature it can take around 45 minutes ${ }^{(10,30)}$. It is noteworthy that, in these situations, the intervention of health professionals, especially nurses, is necessary, adjusting the heated incubator/cradle parameters and implementing actions to reduce heat losses, such as the use of thermal bags and mattresses ${ }^{(30)}$.

In NB, homeothermic control is imperfect, since it has the ability to overheat and cool quickly and has an inability to conserve heat when exposed to thermal stress ${ }^{(37)}$. To achieve improved thermal control, in surgical NB, it is necessary to apply basic thermodynamic principles - reducing heat loss and providing a combination of radiant and conductive heat. Thus, thermal control of neonates must be individualized, continuously monitored with a skin temperature probe throughout hospitalization and associated with continuous monitoring of data on quality of care improvements ${ }^{(38)}$.

Nursing care is necessary and essential for the recovery of NB, which is dependent on fundamental care for the promotion of a thermal environment capable of ensuring its survival, as well as adequate growth and development. Thus, health professionals, and especially nursing, need to be aware of the thermoregulation mechanisms to help NBs achieve thermal neutrality ${ }^{(37)}$.

It is noteworthy that, in order to achieve high levels of thermoregulatory performance, the service team needs to engage in quality improvement (QI) intervention in partnership with other units, given that NICUs that participate in collaborative Ql achieved better results in thermoregulation of those whose efforts are exclusively local ${ }^{(30)}$.

A study shows that during the surgical approach there is a significant number of AEs, which are, in most cases, caused by the lack of a safe practice by health professionals working in the sector, in which the existing safety measures are not used properly ${ }^{(14)}$. This fact is related to the non-compliance with the guidelines recommended by WHO for safe surgery, representing a risk for surgical patients ${ }^{(39)}$.

This research identified actions to prevent hypothermia, which favors reduction of $A E$ in the perioperative period. However, it became evident that there are weaknesses in the implementation of new care technologies, which justifies the need for professionals to rethink their care process, with actions that eradicate the occurrence of neonatal hypothermia ${ }^{(40)}$, as well as launching strategies to improve the prevention of perioperative hypothermia so that it is evaluated in the context of feasibility, effectiveness, safety, acceptability, cost and teamwork ${ }^{(1)}$, to safeguard the OR ideal conditions, taking care of a person, taking care of their individuality and vulnerability before, during and after surgery ${ }^{(41)}$.

Hypothermia in surgical patients is an AE of high incidence and constitutes a public health problem ${ }^{(13)}$. This research identified actions to prevent hypothermia, which favors the reduction of $A E$ in the perioperative period; however, it was evident that there are weaknesses in the implementation of new care technologies, which justifies the need for professionals to rethink their care process, with actions that eradicate the occurrence of neonatal hypothermia.

NB surgical safety depends on actions that aim to prevent the occurrence of preventable $A E$ and when it is not possible to minimize its consequences. Attention to NB hypothermia, during the pre, intra and postoperative period, is of fundamental importance and becomes the focus of nursing care, as it favors the reduction of neonatal morbidity and mortality secondary to hypothermia triggered by the surgical approach.

\section{Study limitations}

This study, because it is an integrative review, has limitations for using secondary data, since the information has already been previously constructed and for having presented a small number of articles. It is also noteworthy that research was restricted to level III of evidence, according to assessment instrument; however, studies have brought good strategies for prevention of hypothermia in NB submitted to surgical procedures. Furthermore, the limited number of studies related to the theme makes it impossible to include more up-to-date references, both in the study's foundation and in the discussion of the study.

\section{Contributions to nursing and health}

This integrative review brings contributions to the health area, especially for neonatal nursing, since: i) identifies strategies for improving clinical and care practices in care for surgical NB; ii) describes actions to prevent hypothermia, which favors the reduction of $\mathrm{AEs}$ in the perioperative period; iii) contributes to the strengthening of international patient safety policies; iv) indicates care strategies that can favor the reduction of neonatal morbidity and mortality; v) points out the need to build an assistance protocol for prevention of hypothermia in surgical NB.

\section{FINAL CONSIDERATIONS}

The evidence in the scientific bases reveals that the main strategies used for prevention of hypothermia in surgical NBs were: room temperature control; establishment of relative air humidity and evaluation of quality of air conditioning cleanliness; use of heated and humidified incubator or heated cradle for hospitalization; operative procedure and transport; use of thermal, chemical mattress or heated blankets in surgical procedures; use of caps, underwear and blanket for heating in the perioperative period; use and infusion of fluids that must be previously heated; monitoring of body temperature in the axillary, nasopharyngeal, esophageal or rectal regions; perioperative temperature measurement routines; coverage of abdominal organs with wet and heated surgical compresses in the intraoperative period; use of environmental heating equipment.

Analyzing the findings of this study, it is recommended to develop further research on this topic, with strong evidence, outlined by methods of randomized clinical trials and cohort studies. Along with this, there is a need for professional training for the use of new technologies and new studies that can investigate the factors that predispose NB to perioperative 
hypothermia, prevention of AEs in the intraoperative period related to thermoregulation and elaboration of protocols based on scientific evidence that aligns the basic principles of thermal control to the new technological resources for prevention of hypothermia to NBs submitted to surgical procedure, among other themes that favor safe practice. In the studies analyzed, episodes of hypothermia were still identified in the surgical NB with the strategies used.

\section{ACKNOWLEDGMENT}

We would like to thank Universidade Federal da Bahia.

\section{REFERENCES}

1. Munday J, Delaforce A, Forbes G, Keogh S. Barriers and enablers to the implementation of perioperative hypothermia prevention practices from the perspectives of the multidisciplinary team: a qualitative study using the Theoretical Domains Framework. J Multidiscip Healthc. 2019;12:395-417. https://doi.org/10.2147/JMDH.S209687

2. World Health Organization-WHO. Thermal protection of the newborn: a practical guide. In: Maternal and Newborn Health/Safe Motherhood Unit (WHO/RHT/MSM/97.2). Geneva: World Health Organization; 1997.

3. Sessler DI. Perioperative thermoregulation and heat balance. Lancet. 2016;25;387(10038):2655-64. https://doi.org/10.1016/S0140-6736(15)00981-2

4. Albuquerque RS, Mariani Neto C, Bersusa AAS, Dias VM, Silva MIM. Newborns' temperature submitted to radiant heat and to the Top Maternal device at birth. Rev Latino-Am Enfermagem. 2016;24:e2741. https://doi.org/10.1590/1518-8345.0305.2741

5. Sousa DS, Sousa Jr AS, Santos ADR, Melo EV, Lima SO, Almeida-Santos MA, et al. Morbidade em recém-nascidos prematuros de extremo baixo peso em unidade de terapia intensiva neonatal. Rev Bras Saúde Matern Infant. 2017;17(1):139-47. https://doi. org/10.1590/1806-93042017000100008

6. Almeida MF, Guinsburg R, Sancho GA, Rosa IR, Lamy ZC, Martinez FE, et al. Hypothermia and early neonatal mortality in preterm infants. J Pediatr. 2014;164(2):271-5. https://doi.org/10.1016/j.jpeds.2013.09.049

7. Perlman JM, Wyllie J, Kattwinkel J, Wyckoff MH, Aziz K, Guinsburg R, et al. Neonatal Resuscitation: 2015 international consensus on cardiopulmonary resuscitation and emergency cardiovascular care science with treatment recommendations. Circulation. 2015;132(Suppl 1):S204-41. https://doi.org/10.1542/peds.2015-3373D

8. World Health Organization (WHO). Patient safety: about us[Internet]. c2009-2018 [cited 2021 Mar 06]. Geneva: WHO; Available from: http:// www.who.int/patientsafety/about/en/

9. Wegner W, Silva MUM, Peres MA, Bandeira LE, Frantz E, Botene DZA, et al. Patient safety in the care of hospitalised children: evidence for paediatric nursing. Rev Gaúcha Enferm. 2017;38(1):e68020. https://doi.org/10.1590/1983- 1447.2017.01.68020

10. Don Paul JM, Perkins EJ, Pereira-Fantini PM, Suka A, Farrell O, Gunn JK, et al. Surgery and magnetic resonance imaging increase the risk of hypothermia in infants. J Paediatr Child Health. 2018;54(4):426-31. https://doi.org/10.1111/jpc.13824

11. Morehouse D, Williams L, Lloyd C, McCoy DS, Miller Walters E, Guzzetta CE, et al. Perioperative Hypothermia in NICU Infants. Adv Neonatal Care. 2014;14(3):154-64. https://doi.org/10.1097/ANC.0000000000000045

12. Matlow AG, Baker GR, Flintoft V, Cochrane D, Coffey M, Cohen E, et al. Adverse events among children in Canadian hospitals: the Canadian Pediatric Adverse Events Study. CMAJ. 2012;184(13):E709-18. https://doi.org/10.1503/cmaj.112153

13. Bindu B, Bindra A, Rath G. Temperature management under general anesthesia: compulsion or option. J Anaesthesiol Clin Pharmacol. 2017;33(3):306-16. https://doi.org/10.4103/joacp.JOACP_334_16

14. Corona ARPD, Peniche ACG. A cultura de segurança do paciente na adesão ao protocolo da cirurgia segura. Rev SOBECC. 2015;20(3):179-85. https://doi.org/10.5327/Z1414-4425201500030009

15. Martins LA, Silveira SPX, Avila IMFT, Moraes JAS, Santos DSS, Whitaker COM, et al . Thermoregulation protocol implementation for newborns in surgical procedures. Rev Gaúcha Enferm. 2019;40(spe):e20180218. https://doi.org/10.1590/1983-1447.2019.20180218

16. Engorn BM, Kahntroff SL, Frank KM, Singh S, Harvey HA, Barkulis CT, et al. Perioperative hypothermia in neonatal intensive care unit patients: effectiveness of a thermoregulation intervention and associated risk factors. Paediatr Anaesth. 2017;27(2):196-204. https://doi. org/10.1111/pan.13047

17. Mendes KDS, Silveira RCCP, Galvão CM. Revisão integrativa: método e pesquisa para a incorporação de evidências na saúde e na enfermagem. Texto Contexto Enferm. 2008;17(4):758-64. https://doi.org/10.1590/S0104-07072008000400018

18. Whittemore R, Knafl K. The integrative review: updated methodology. J Adv Nurs. 2005;52(5):546-53. https://doi. org/10.1111/j.1365-2648.2005.03621.x

19. Santos CMC, Pimenta CAM, Nobre MRC. A estratégia PICO para a construção da pergunta de pesquisa e busca de evidências. Rev Latino-Am Enfermagem. 2007;15(3):508-11. https://doi.org/10.1590/S0104-11692007000300023

20. Moola S, Munn Z, Tufanaru C, Aromataris E, Sears K, Sfetcu R, et al. Chapter 7: systematic reviews of etiology and risk. In: Aromataris E, Munn Z (Editors). Joanna Briggs Institute Manual for Evidence Synthesis. The Joanna Briggs Institute, 2020. https://doi.org/10.46658/JBIMES-20-08 
21. Lizarondo L, Stern C, Carrier J, Godfrey C, Rieger K, Salmond S, et al. Chapter 8: Mixed methods systematic reviews. In: Aromataris E, Munn Z (Editors). Joanna Briggs Institute Manual for Evidence Synthesis. The Joanna Briggs Institute, 2020. https://doi.org/10.46658/JBIMES-20-09

22. Miles MB, Huberman M. Drawing valid meaning from qualitative data: toward a shared craft. Educational researcher, 1984.

23. Moher D, Liberati A, Tetzlaff J, Altman DG. Preferred reporting items for systematic reviews and metaanalyses: the PRISMA statement. Int J Surg. 2010;8(5):336-41. https://doi.org/10.1136/bmj.b2535

24. Tsingoglou S, Wilkinson AW. Heat loss during neonatal operations. Arch Dis Child. 1971;46:452. https://doi.org/10.1136/adc.46.248.452

25. Tander B, Baris S, Karakaya D, Ariturk E, Rizalar Z, Bernay F. Risk factors influencing inadvertent hypothermia in infants and neonates during anesthesia. Paediatr Anaesth. 2005;15(7):574-9. https://doi.org/10.1111/j.1460-9592.2005.01504.x

26. He ZR, Lin TI, Ko PJ, Tey SL, Yeh ML, Wu HY, et al. The beneficial effect of air cleanliness with ISO 14644-1 class 7 for surgical intervention in a neonatal intensive care unit: a 10-year experience. Medicine (Baltimore). 2018;97(36):e12257. https://doi.org/10.1097/MD.0000000000012257

27. Joseph RA, Derstine S, Killian M. Ideal site for skin temperature probe placement on infants in the NICU. Adv Neonatal Care. 2017;17(2):11422. https://doi.org/10.1097/ANC.0000000000000369

28. Yip WY, Quek BH, Fong MCW, Thilagamangai L, Ong SSG, Lim BL, et al. A quality improvement project to reduce hypothermia in preterm infants on admission to the neonatal intensive care unit. Int J Qual Health Care. 2017;29(7):922-8. https://doi.org/10.1093/intqhc/mzx131

29. Lourenção DC, Tronchin DM. Patient safety in the surgical environment: translation and cross-cultural adaptation of validated instrument. Acta Paul Enferm. 2016;29(1):1-8. https://doi.org/10.1590/1982-0194201600002

30. Pinheiro JMB. Preventing hypothermia in preterm newborns: simple principles for a complicated task. J Pediatr. 2018;94(4):337-9. https:// doi.org/10.1016/j.jped.2017.10.003

31. Trevisanuto D, Testoni D, Almeida MFB. Maintaining normothermia: why and how?. Semin Fetal Neonatal Med. 2018;23(5):333-9. https://doi. org/10.1016/j.siny.2018.03.009

32. Meng-Meng T, Xue-Jun X, Xiao-Hong B. Clinical effects of warmed humidified carbon dioxide insufflation in infants undergoing major laparoscopic surgery. Medicine (Baltimore). 2019;98(27):e16151. https://doi.org/10.1097/MD.0000000000016151

33. Bernardis RCG, Silva MP, Gozzani JL, Pagnocca ML, Mathias LAST. Uso da manta térmica na prevenção da hipotermia intraoperatória. Rev Assoc Med Bras. 2009;55(4):421-6. https://doi.org/10.1590/S0104-42302009000400017

34. Liu X, Shi Y, Ren C, Li X, Zhang Z. Effect of an electric blanket plus a forced-air warming system for children with postoperative hypothermia: a randomized controlled trial. Medicine (Baltimore). 2017;96(26):e7389. https://doi.org/10.1097/MD.0000000000007389

35. Pereira NHC, Rocha AM, Mattia AL. Infusão venosa aquecida relacionada à prevenção das complicações da hipotermia intraoperatória. Rev SOBECC. 2014;19(2):74-8. https://doi.org/10.4322/sobecc.2014.013

36. Schroeck H, Lyden AK, Benedict WL, Ramachandran SK. Time trends and predictors of abnormal postoperative body temperature in infants transported to the intensive care unit. Anesthesiol Res Pract. 2016;2016:7318137. https://doi.org/10.1155/2016/7318137

37. Pimenta PCO, Alves VH. Interhospital transport of the high-risk newborn: a challenge for the nursing staff. Cogitare Enferm. 2016;21(esp):0109. https://doi.org/10.5380/ce.v21i5.45047

38. Caldas JP, Millen FC, Camargo JF, Castro PA, Camilo AL, Marba ST. Effectiveness of a measure program to prevent admission hypothermia in very low-birth weight preterm infants. J Pediatr. 2018;94:368-73. https://doi.org/10.1016/j.jped.2017.06.016

39. Almeida RE, Rodrigues MS. Implementation of the surgical safety checklist for pediatric operations: compliance assessment. Rev Gaúcha Enferm. 2019;40(esp):e20180270. https://doi.org/10.1590/1983-1447.2019.20180270

40. Espindola S, Nascimento KC, Knihs NS, Alvarez AG, Sebold LF, Paim SMS. Intraoperative patient safety during liver transplantation: integrative review. Acta Paul Enferm. 2020;33:e-APE20180187. https://doi.org/10.37689/acta-ape/2020ar0187

41. Penaforte H, Sá C, Seara L, Costa MJ, Mendes A. Normotermia no perioperatório: perspetiva do enfermeiro. Rev Investig Inov Saúde. 2019;2(1):7-17. https://doi.org/10.37914/riis.v2i1.43 